\title{
Geology, Geochemistry and Hydrothermal Fluid Characteristics of Low Sulfidation Epithermal Deposit in the Sangon Area, Kokap, Special Region of Yogyakarta
}

\author{
Pranayoga Pramumijoyo ${ }^{* 1}$, Arifudin Idrus ${ }^{1}$, I Wayan Warmada ${ }^{1}$, and Kotaro Yonezu ${ }^{2}$ \\ ${ }^{1}$ Department of Geological Engineering, Faculty of Engineering, Gadjah Mada University, Yogyakarta, Indonesia \\ ${ }^{2}$ Department of Earth Resources Engineering, Kyushu University, Japan
}

\begin{abstract}
On the basis of the previous studies and reconnaissance survey in the study area covering Sangon, Kalirejo, Kokap Sub-district, Kulon Progo Regency, Special Region of Yogyakarta, it reveals some facts of the occurrence of quartz veins with massive, crustiform, comb, drusy cavity, saccharoidal, granular, and reniform/mammillated textures, the appearance of lattice bladed barite and hydrothermal breccia veins. Referring to those characteristics, the deposit type in the study area is interpreted to be low sulfidation epithermal type. This study is aimed to understand and characterize the geological condition, rock and ore geochemistry and the mineralizing fluids. The alteration and ore mineralization are almost observed in entire rock units particularly the intrusive andesite 1. Their formation is controlled by the tension fractures (NW-SE and NE-SW) which associate with sinistral strike slip faults (NE-SW), dilational jog (NNW-SSE), oblique normal fault (WNW-ESE), and predictable normal fault at the NE of study area (NW-SE). The alteration zones are developed to be silica-clay (quartz-illite-kaolinite-kaolinite/smectite), argillic (smectite-illite/smectite), and propylitic (chlorite-calcite \pm epidote). The precipitation of ore minerals is controlled by boiling, mixing, and wall-rock alteration, and can be found in the quartz veins (quartz-adularia-sericite) and disseminated in the alteration zones, which their high variability is only can be found in the quartz veins, including pyrite, sphalerite, chalcopyrite, galena, marcasite, and arsenopyrite. Based on the ICPAES measurement of 5 quartz vein samples, the $\mathrm{Cu}, \mathrm{Zn}, \mathrm{Pb}$, and As grade reach about 5,171 ppm, 8,995 ppm, 6,398 ppm, $34.1 \mathrm{ppm}$, and 1,010.5 ppm, respectively. Gold is not detected. Fluid inclusion microthermometric analysis shows $\mathrm{T}_{\mathrm{h}}$ of $242.1-257.6^{\circ} \mathrm{C}$ and salinity of 1.57-3.87 wt.\% NaCl equiv., which indicate a depth below the paleosurface of $384-516 \mathrm{~m}$, and pressure of 101.7-136.6 bar. The ore deposit in the study area is interpreted to be a deep basemetal low sulfidation epithermal type. Gold might be depleted in this epithermal type.
\end{abstract}

Keywords: Low sulfidation epithermal · Andesite · Alteration · Ore mineralization $\cdot$ Hydrothermal fluid · Sangon.

\section{INTRODUCTION}

Indonesia is an archipelagic country traversed by magmatic arcs, which are associated with the occurrences of economic ore mineraliza-

\footnotetext{
${ }^{*}$ Corresponding author: P. PRAMUMIJOYO, Department of Geological Engineering, Gadjah Mada University. Jl. Grafika 2 Yogyakarta, Indonesia. E-mail: pranayogapramumijoyo@gmail.com
}

tion zones, including epithermal deposits, as the second largest gold deposit after porphyry (Carlile and Mitchell, 1994). Although gold is always be a main target of that deposits, it also can contain valuable base metals, such as $\mathrm{Cu}, \mathrm{Pb}$, and $\mathrm{Zn}$ (Simmons et al., 2005). Based on the preliminary survey, can be found strike slip faults (NW-SE, and dominantly have NE-SW orientation) which are associated with 
the NW-SE and NE-SW quartz veins. These veins have crustiform, comb, drusy cavity, saccharoidal, granular, and reniform or mammillated textures. Hydrothermal breccia and lattice bladed barite veins, also argillic and propylitic alteration zones are also found in this area. According to those evidences, can be assumed that the deposit type in the research area is belongs to low sulfidation epithermal. This study is aimed to understand and characterize the geological condition, rock and ore geochemistry and the mineralizing fluids.

\section{Regional Geology}

Physiographically, the research area is a part of the Kulon Progo Mountains, and according to Van Bemmelen (1949), they are composed of highly eroded Oligocene - Miocene Old Andesite Volcano complexes, namely Gadjah Volcano (located at the middle part and initially generated), Idjo Volcano which occupies the southern part (including the research area), and Menoreh Volcano at the northern part, which formed at the end, after the extinction and denudation of Gadjah Volcano. Based on Rahardjo et al. (1995), Kulon Progo Mountains are consisted of four rock formations and a quarternary alluvial, colluvial, and volcanic deposit. From the oldest to the youngest, those rock formations are including the Nanggulan Formation (Middle Eocene - Lower Oligocene), Old Andesite Formation (Upper Oligocene - Lower Miocene), Jonggrangan Formation (Lower - Middle Miocene), and Sentolo Formation (Lower Miocene - Upper Pliocene).

In addition, there are also igneous intrusive complexes surrounding the Idjo Volcano. A dacite stock can be found at the Watunoman and Curug Hill (Suroso et al., 1986), andesite intrusion at Idjo Hill $(25.98 \pm 0.55 \mathrm{Ma}$ (Upper Oligocene)) and Kukusan Hill (29.24 \pm $2.38 \mathrm{Ma}$ (Upper Oligocene)) (Soeria-Atmadja et al., 1994). According to Harjanto (2011), Kulon Progo Mountains have at least two tectonic events. The NE-SW and N-S compressional stress cause the formation of strike slip faults, folds, and tension fractures in the Old Andesite Formation. These geological structures are then intruded by andesite and dacite, and further filled by quartz veins (Soeria-Atmadja et al., 1994).

\section{Research Methods}

The methods utilized in this research can be classified into two groups, that are fieldwork and laboratory analyses. The fieldwork includes geological and hydrothermal alteration zone mapping on a 1:25,000 scale, as well as collecting rock and vein samples. The laboratory analyses comprised of petrographic analysis (18 samples), ore microscopy analysis (9 samples), X-ray Diffraction (XRD) analysis (11 samples), Scanning Electron MicroscopyEnergy Disperse Spectroscopy (SEM/EDS) (7 samples), X-ray Fluorescence (XRF) analysis (17 samples), Inductively-Coupled Plasma-Atomic Emission Spectroscopy (ICP-AES) analysis (18 samples), and microthermometry analysis (4 samples). These laboratory analyses were done at Economic Geology Laboratory, Department of Earth Resources Engineering, Kyushu University, Japan and Laboratory of Central Geology, Department of Geological Engineering, Universitas Gadjah Mada.

\section{Results AND Discussion}

\subsection{Geology of research area}

The research area can be divided into two geomorphic units, namely intrusion dome and faulted hill, which the former unit naming is based on its tight, relatively rounded, and isolated contour patterns. There are six rock units in the research area (Figure 1), from the oldest, they are including quartz wacke, intrusive andesite 1 , intrusive andesite 2 , diatreme breccia, intrusive andesite 3 , and intrusive dacitic andesite. The quartz wacke is assumed to be a part of Axinea Beds in the Nanggulan Formation. It is composed of quartz wacke and lithic wacke, that have lamination structure with $\mathrm{N}$ $112,5^{\circ} \mathrm{E} / 55^{\circ}$ trend.

The intrusive andesite 1 unit is composed of andesite and hornblende andesite, andesite 2 intrusion unit consists of the brightest colored andesite, and diatrema breccia unit composed of diatrema breccia and andesite dike, which is thought to be formed after andesite intrusion unit 2. The intrusive andesite 3 unit has the same rock texture (coarse) with intrusive dasitic andesite unit. The difference between these two units is based on the presence of primary quartz which is quite abundant in the dasitic andesitic intrusion unit. The intrusive dacitic andesite is 


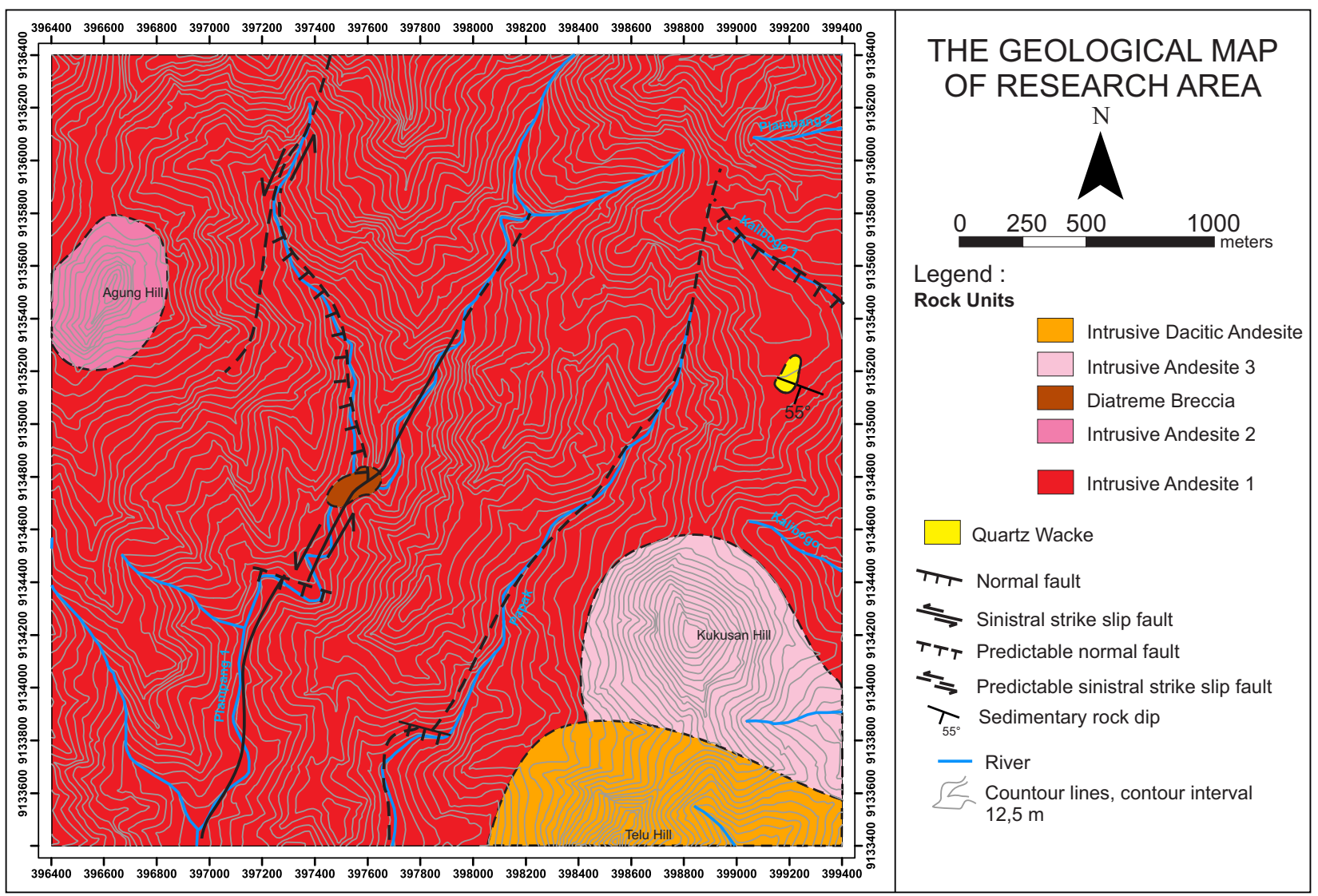

Figure 1: The geological map of research area.

determined as the last formed unit, after the intrusive andesite 3 .

There are five geological structures in the research area (Figure 1), including NW-SE and NE-SW tension fractures, as quartz veins, that have comb, crustiform, colloform, saccharoidal, granular, drusy cavity, dog teeth, tower-like, reniform-saccharoidal, to massive textures, and also as lattice bladed barite (Figure 2a) and hydrothermal breccia veins (Figure $2 b$ ). They are associated with the sinistral strike slip faults (NE-SW), and a NNW-SSE predictable normal fault as dilational jog. Those geological structures are the result of NNE-SSW compressional stress. At the extensional phase, there are oblique normal faults (WNW-ESE), and a normal fault at the northeastern part of the research area (NW-SE).

\subsection{Hydrothermal alteration and ore miner- alization}

The alteration and ore mineralization zones in the research area are strongly controlled by orientation and distribution of the geological structures (Figure 3), and highly observed in the intrusive andesite 1 unit. There are three types of hydrothermal alteration including silicaclay (quartz-illite-kaolinite-kaolinite/smectite), argillic (smectite-illite/smectite), and propylitic (chlorite-calcite \pm epidote). The variability and amount of the ore minerals in the quartz veins (quartz-adularia-sericite) (pyrite-sphalerite \pm chalcopyrite-galena-marcasite-arsenopyrite)

(Figure 2c-d) are higher than in the alteration zones (silica-clay: pyrite \pm marcasitechalcopyrite, argillic and propylitic: pyrite). Some oxide minerals can aslo be found. They occur as a result of the supergene process (oxidation), including goethite and anatase, which can be identified both in the vein and silica-clay alteration zone, whereas covellite (Figure 2e-f) is restricted in the vein, and hematite in the silica-clay alteration zone. Based on the relationship of the ore minerals growth (Table 1), can be determined that arsenopyrite is firstly formed, then followed by the sphalerite and galena. 

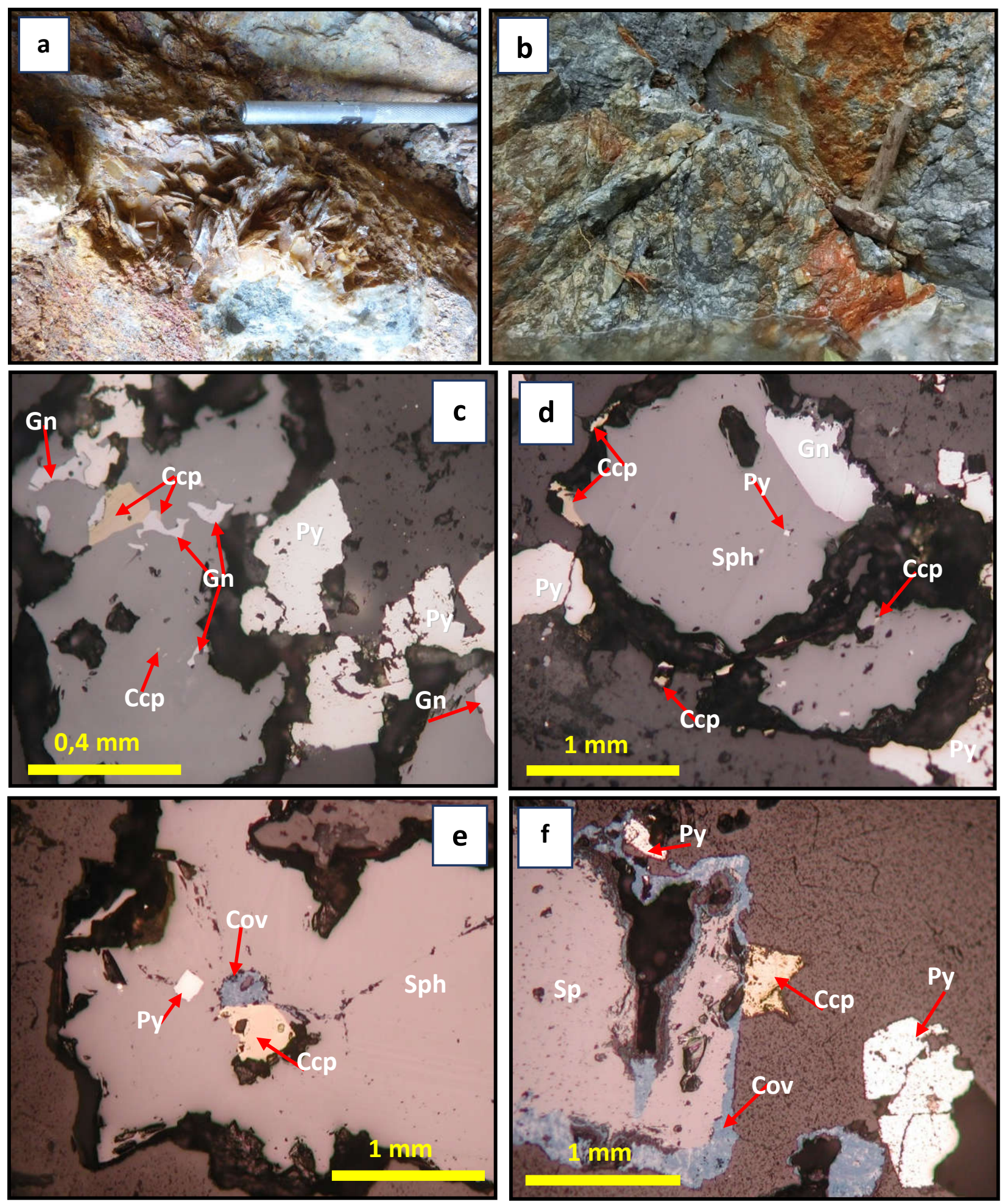

Figure 2: Lattice bladed (a), and hydrothermal breccia (b) vein textures. The growth relationship of some ore minerals and an oxide mineral under reflection microscope of samples 18.7 (c-d) and 5.1 (e-f). (a-b) Sphalerite, galena, chalcopyrite, and pyrite. (e-f) Sphalerite, chalcopyrite, pyrite, and covellite. Sph: sphalerite, Gn: galena, Ccp: chalcopyrite, Py: pyrite, Cov: covellite. 


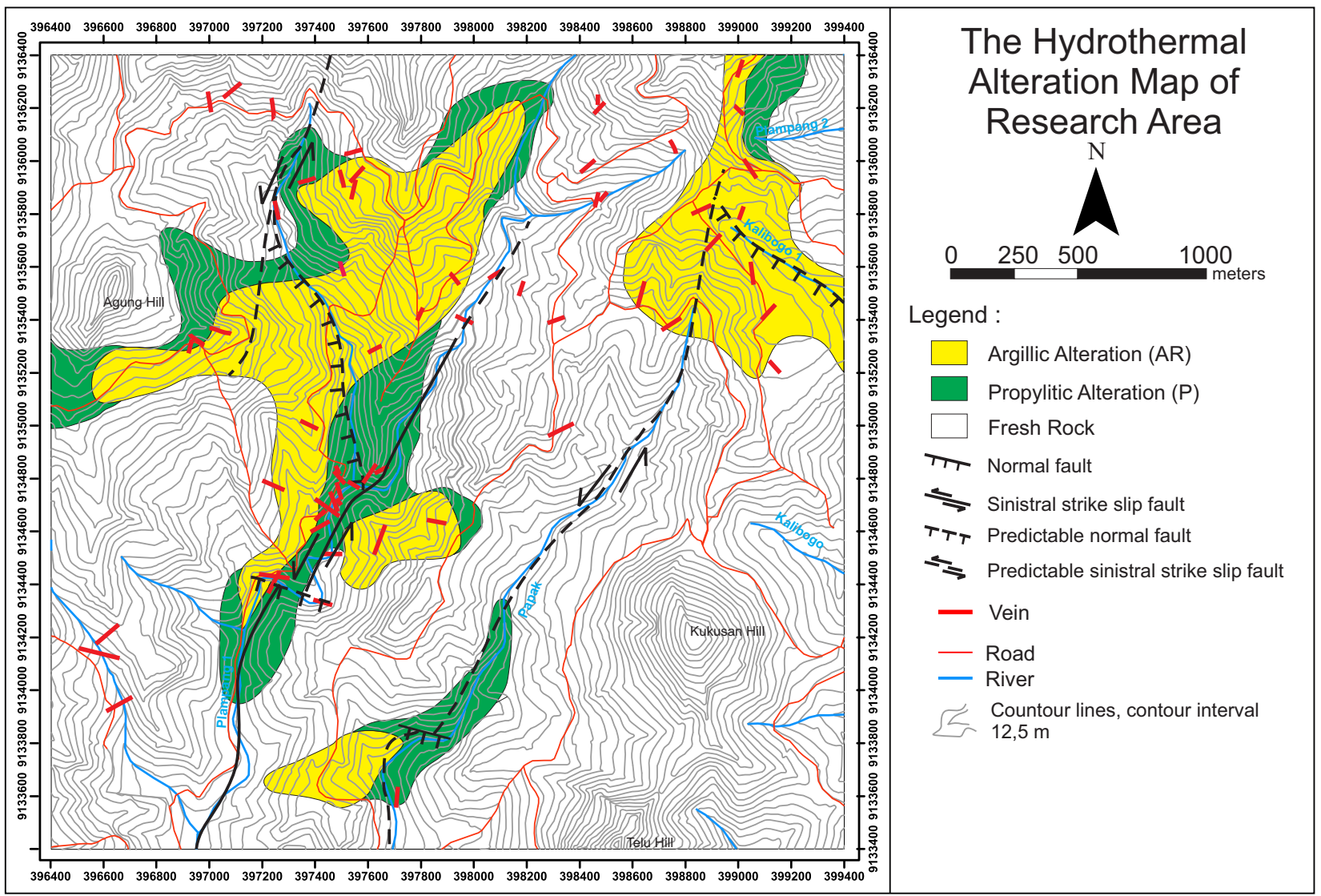

Figure 3: The hydrothermal alteration map of research area.

Table 1: Ore minerals paragenesis in the quartz vein.

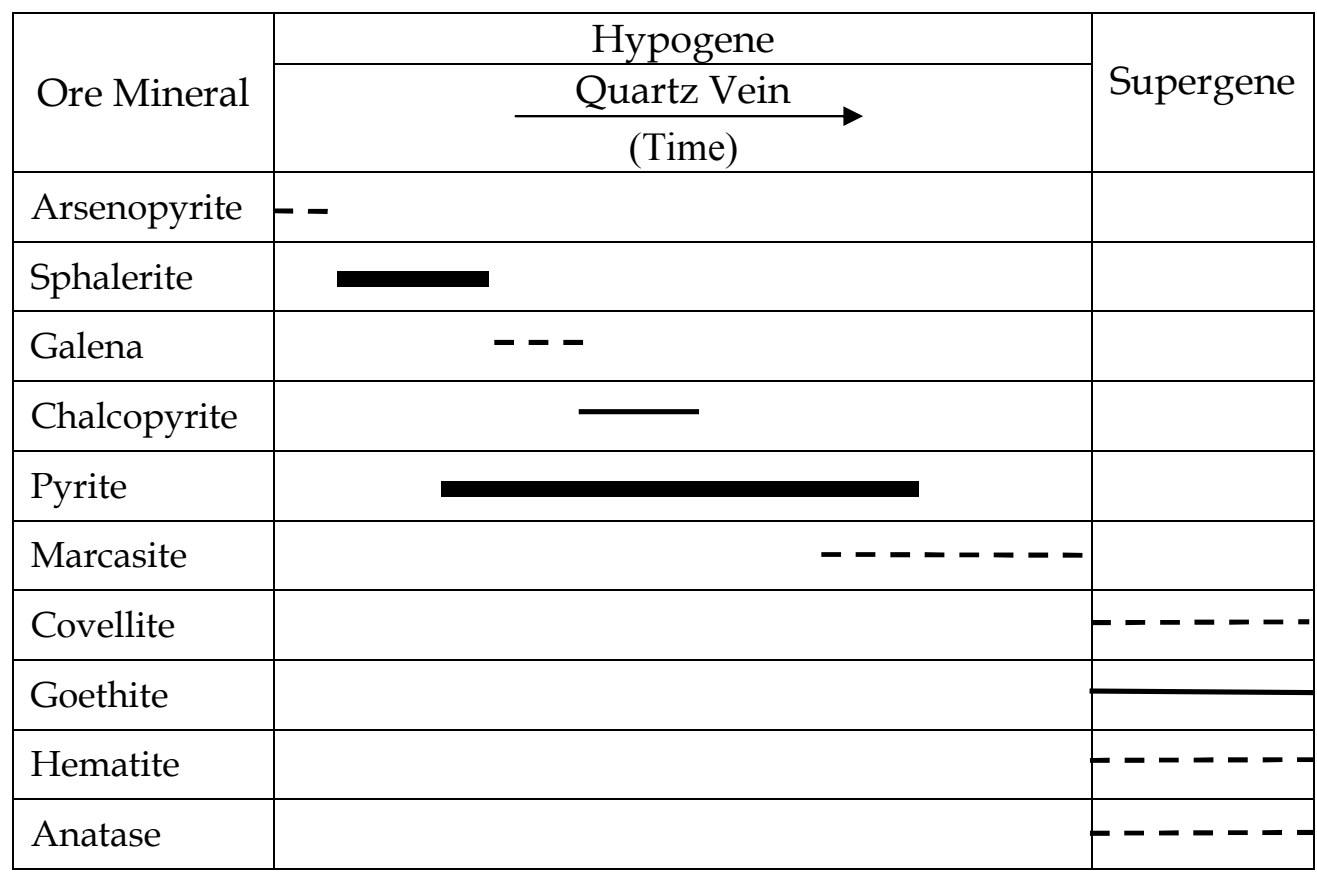

abundant - quiteabundant

slightly abundant

- - - - - - , rare 


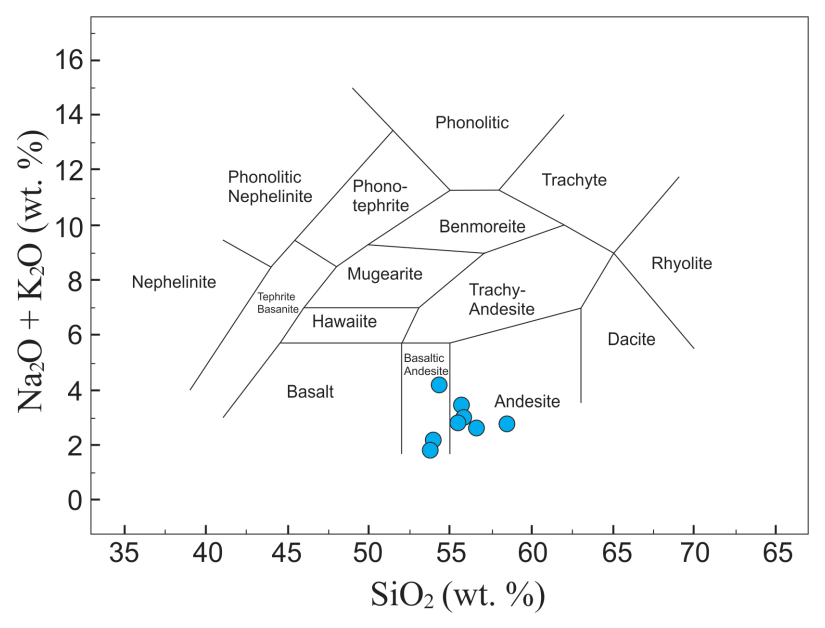

Figure 4: Andesite and basaltic andesite as the result of TAS diagram Cox, et al. (1979, in Petrelli et al., 2005) plotting.

\subsection{Geochemistry of whole rock and hy- drothermal alteration}

Due to the alteration and ore mineralization are almost entirely found in the intrusive andesite 1 unit, the host rock geochemical analysis is only conducted for the member of that unit. Based on the plotting result in the TAS (Total Alkali versus Silica) diagram of Cox et al. (1979, in Petrelli et al., 2005) (Figure 4), can be confirmed that this unit is consisted of andesite and basaltic andesite (equivalent to hornblende andesite). The plotting result in the harker diagram (Figure 5) generally shows positive trends toward $\mathrm{Na}_{2} \mathrm{O}$ and $\mathrm{K}_{2} \mathrm{O}$, also opposite trends of $\mathrm{MgO}$ and total $\mathrm{FeO}$ against the $\mathrm{SiO}_{2}$, which indicates differentiation (fractional crystallization) as a process that affects the magma evolution in the research area. That result is proved with the little existence of hornblende andesite, because it already differentiated into andesite. Both of that andesite have calc-alkaline affinity based on AFM diagram after Kuno (1968, in Petrelli et al., 2005) (Figure 6), which indicate a magma that produced in the convergence plate tectonic setting, as the research area take place.

The geochemistry of hydrothermal alteration only can be identified based on the $\mathrm{K}_{2} \mathrm{O}$ enrichment, which indicates the illite existence, both as identification-mark mineral in the silicaclay alteration zone, and also as overprinting mineral in the other alteration zones. Sericite is commonly found in every alteration zone, and its appearance is indicated by the $\mathrm{Rb}$ en- richment, whereas the depletion of $\mathrm{FeO}$ and $\mathrm{MgO}$ are preferably related to the breakdown of hornblende and clinoproxene. The $\mathrm{Na}_{2} \mathrm{O}$ depletion may correspond to the plagioclase depletion. According to Idrus et al. (2009), the $\mathrm{CaO}$ depletion may suggest that the calcium concentration is controlled by the replacement of calcic plagioclase (intensive changing in the plagioclase rims). The result of mass balance analysis also shows the mass and volume changes in the host rock because of the hydrothermal alteration (Figure 7).

The silica-clay and argillic alteration lead the mass and volume enrichment to the host rock, sequentially by $85.71 \%$ and $115.23 \%, 35.82 \%$ and $72.08 \%$, whereas the propylitic, causes a depletion by $6.19 \%$ and $1.92 \%$. Based on the ICP-AES result, can be known that there are high concentration of base metal elements like $\mathrm{Cu}, \mathrm{Zn}$, and $\mathrm{Pb}$, which reach 5,17 ppm, 9,0 ppm, and 6,4 ppm, and a high grade of As, which reaches $1,010.5 \mathrm{ppm}$. Besides, it also represents a little concentration of $\mathrm{Ag}$, ranged from 6.2-34.1 ppm, and Mo, which only reaches $96.9 \mathrm{ppm}$. Gold is not detected.

\subsection{Hydrothermal fluid characteristics}

The fluid inclusion analysis is only conducted on the primary inclusions in totally four veins, which consist of two quartz veins, and two crustiform calcite veins (with quartz that contains rich sulfide minerals), with each total measurement number as many as 20,19, 21, and 20 inclusions. According to Shepherd et al. (1985), the fluid inclusions in the research area can be classified as an aqueous, liquid-rich (with gas content $<50 \%(9.7-40.8 \%)$ ), two-phase inclusions. Those inclusions commonly have tabular, irregular, and relatively rounded shapes (Figure 8).

Generally, the $T_{h}$ value of the fluid inclusion in the research area ranged from $242.1-246.3^{\circ} \mathrm{C}$ and $251.3-257.6^{\circ} \mathrm{C}$, with salinity ranged from $1.57-3.87$ wt. $\% \mathrm{NaCl}$ equiv. Those values indicate the fluid trapping condition, and indirectly show the temperature and salinity forming deposit. The depth of trapping is determined by using after Haas diagram (1971, in Shepherd et al., 1985), which indicates the depth of the deposit. The result reveals a depth ranged from 384-516 m below paleosurface, which used to calculate the pressure forming deposit by using 
PRAMUMIJOYO et al.
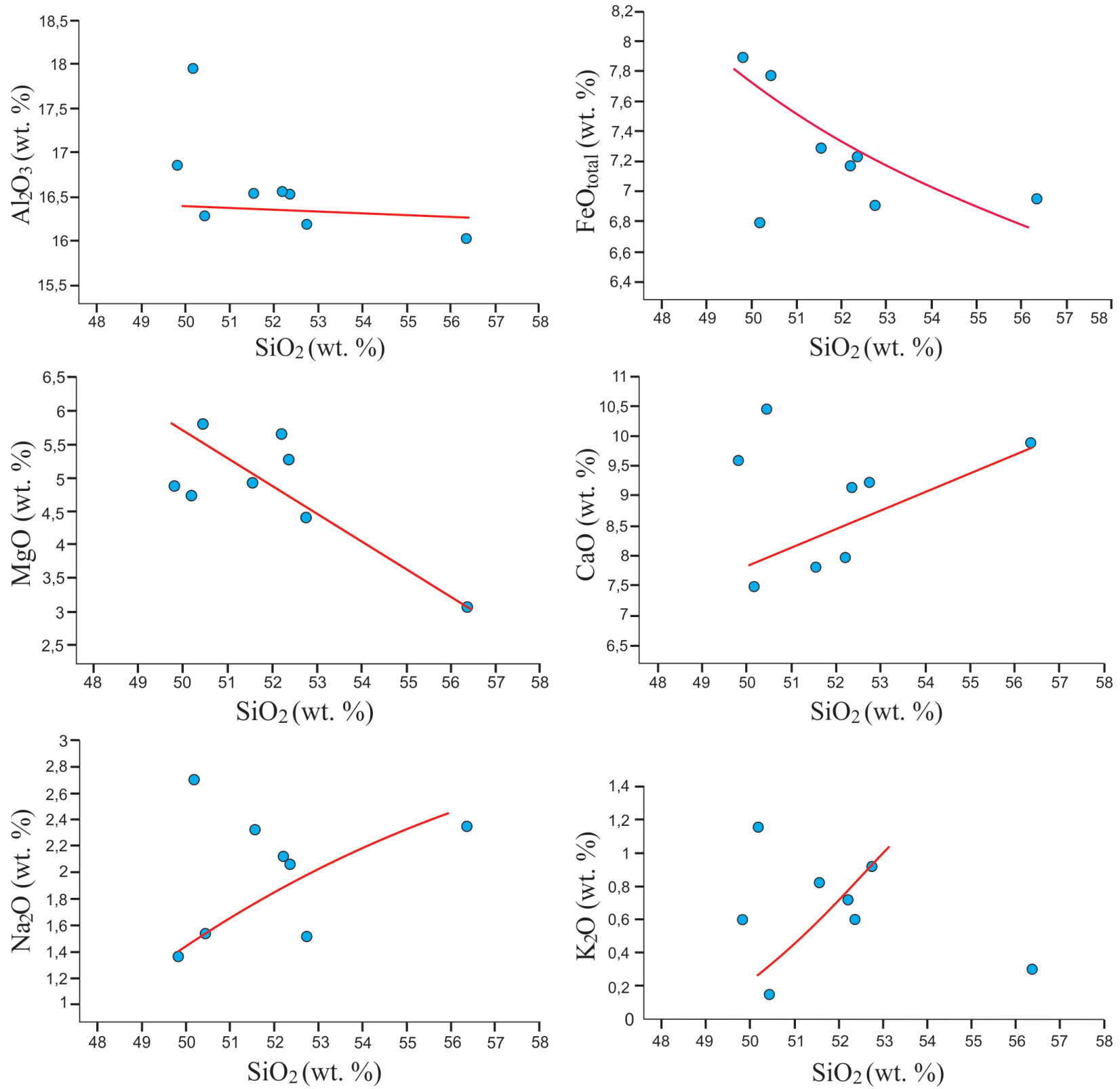

Figure 5: Harker diagram of Intrusive Andesite 1 lithologies (andesite and hornblende andesite). 


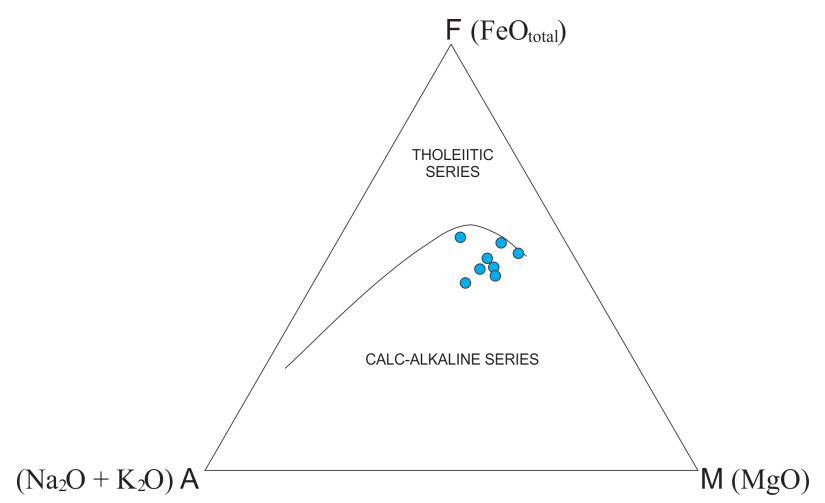

Figure 6: Calc-alkaline magma affinity in after Kuno AFM diagram (1968, in Petrelli et al., 2005).

formula $P=H \rho g$ in the Shepherd et al. (1985). Based on the calculation result, can be known a pressure of 102-137 bar.

The interpretation of hydrothermal fluid is done by plotting the homogenization temperature values $\left(\mathrm{T}_{\mathrm{h}}\right)$ against the salinity values, and correlate the trends to the $\mathrm{T}_{\mathrm{h}}$-salinity trend according to Wilkinson (2001). Based on that activity, can be identified that heating occurs in every vein, and it is proven by the appearance of some inclusions that indicate the early necking down process. Besides, there is also isothermal mixing, which indicated by constant $T_{h}$ range in three veins, with value range about 251.3-257. $6^{\circ} \mathrm{C}$. Those processes may take a role as the high salinity values range causal. That plotting result also indicates boiling process in the quartz vein sample, which supported by its association with barite vein and the appearance of the highest grade of $\mathrm{Zn}$ and $\mathrm{Pb}(8,995 \mathrm{ppm}$ and 6,398 ppm).

\section{Discussion}

\subsection{Geological aspects controlling alteration and ore mineralization}

The hydrothermal alteration and the ore mineralization are controlled by geological structures in the research area, including tension fractures (NW-SE and NE-SW) which associate with the sinistral strike slip faults (NE-SW), and a normal fault (dilational jog) (NNW-SSE), also oblique normal fault (WNW-ESE), and a normal fault in the northeastern part in the research area (NW-SE). Those extensional structures play an important role as channelways for the hydrothermal fluid to flow to the shallower depth, and yields the alteration and ore mineralization zones, which confirmed by their distribution and the orientation that relatively follow the geological structures distribution.

\subsection{Deposit type and model}

According to the low sulfidation epithermal deposit classification by Hedenquist et al. (2000), and Sillitoe and Hedenquist (2003), can be known that the deposit type in the research area is deep low sulfidation epithermal (Table 2). That result is determined based on the some characteristics similarity, including the calc-alkaline andesite as the host rock, the occurrence of ore mineralization in the veins and disseminated in the altered host rock, quartz and sericite as the dominant gangue minerals, barite veins which occasionally associate with quartz veins, crustiform carbonate (calcite) veins as ore bearing veins (rarely seen), the assemblage of ore minerals such as pyrite, sphalerite, galena, and chalcopyrite, high grade value of some metal elements including $\mathrm{Cu}, \mathrm{Zn}$, and $\mathrm{Pb}(5,171 \mathrm{ppm}, 8,995 \mathrm{ppm}$, and 6,398 ppm), and salinity value ranged from 1.57 to $3.87 \mathrm{wt} . \%$ $\mathrm{NaCl}$ equiv.

The depth of mineralization formation in the study area estimated from fluid inclusions was obtained ranging from $384-516 \mathrm{~m}$ below the paleosurface. This is also supported by several characteristics similar to the Buchanan model (1981, in Morrison et al., 1990), such as the occurrence of sphalerite, galena, pyrite, and chalcopyrite, also Ag existence in one of the analyzed veins, the presence of gangue minerals including pyrite, arsenopyrite, and quartz, also quartz veins with adularia, and the identified crustiform quartz-calcite vein.

Cooke and Simmons (2000) stated that the indication of the boiling and mixing is characterized by the homogenization temperature of $180-270{ }^{\circ} \mathrm{C}$, with the same value of melting temperature in general. That statement is supporting the boiling occurrence in the research area and also indicates the mixing process at once, which are responsible for the ore mineral precipitation. The evidence of mixing also supported by the association of quartz veins with propylitic alteration, either directly or indirectly. Besides both of those processes, there is also wall rock sulfidation, which is indicated 

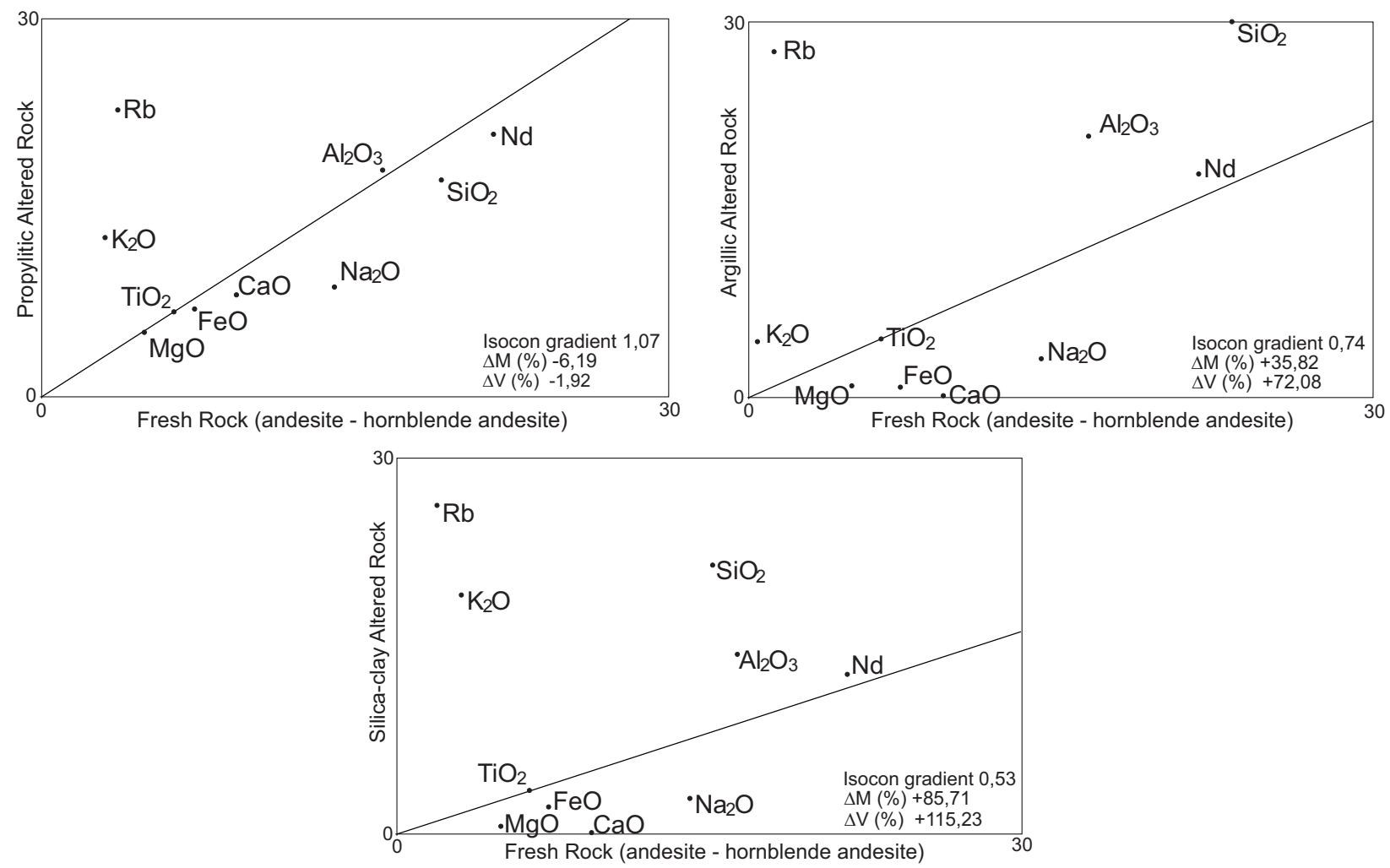

Figure 7: Isocon diagrams of the altered rock against fresh rock.
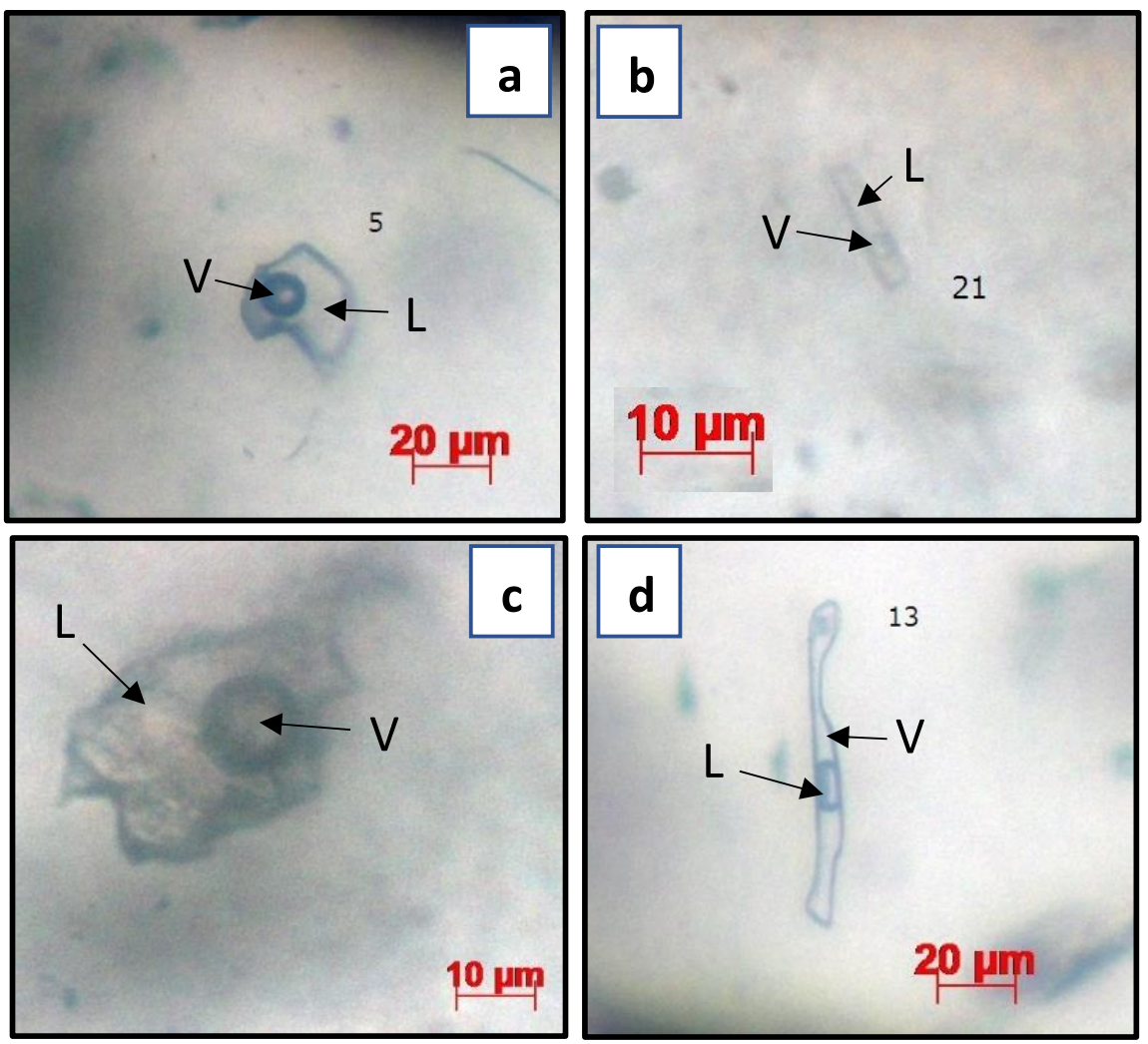

Figure 8: The morphology of primary fluid inclusion. (a) Relatively rounded. (b) Tabular. (c) Irregular. (d) Initialnecking-down in the tabular fluid inclusion.L: liquid, V: vapor. 
Table 2: The type of low sulfidation epithermal deposit in the research area (inside the red box) in the epithermal deposit classification according to Hedenquist et al., 2000; Sillitoe and Hedenquist, 2003 (modified).

\begin{tabular}{|c|c|c|}
\hline \multicolumn{3}{|c|}{ Low Sulfidation Epithermal Deposit } \\
\hline \multirow{2}{*}{ Depth } & Shallow & Deep \\
\hline & $0-300 \mathrm{~m}$ & $300-800 \mathrm{~m}$ (>1000 m: rarely) \\
\hline $\begin{array}{c}\text { Genetically } \\
\text { Related } \\
\text { Volcanic Rock }\end{array}$ & $\begin{array}{c}\text { Basalt-rhyolite/bimodal rhyodacite } \\
\text { calc-alkaline, alkaline, } \\
\text { tholeiitic }\end{array}$ & $\begin{array}{c}\text { Andesite-rhyodacite } \\
\text { (or rhyolite, locally), calc-alkaline }\end{array}$ \\
\hline Deposit Form & $\begin{array}{l}\text { Vein, vein swarm, stockwork, } \\
\text { disseminated }\end{array}$ & Vein, breccia body, disseminated \\
\hline Ore Textures & $\begin{array}{l}\text { Fine bands, comb, crustiform, } \\
\text { colloform, breccia }\end{array}$ & Coarse bands, comb, crustiform \\
\hline Alteration & $\begin{array}{l}\text { Alunite-kaolinite (blanket), clay } \\
\text { halo }\end{array}$ & $\begin{array}{l}\text { Clays, sericite, carbonates; } \\
\text { roscoelite, fluorite }\end{array}$ \\
\hline Gangue & Chalcedony-adularia-illite, calcite & $\begin{array}{l}\text { Quartz-carbonate-rhodonite- } \\
\text { sericite-adularia (uncommon) } \pm \\
\text { barite } \pm \text { anhydrite } \pm \text { hematite } \pm \\
\text { chlorite }\end{array}$ \\
\hline Sulfides & $\begin{array}{c}\text { Cinnabar, stibnite; } \\
\text { pyrite/marcasite-arsenopyrite, Au- } \\
\text { Ag selenides, Se sulfosalts, } \\
\text { pyrrhotite, Fe-rich sphalerite }\end{array}$ & $\begin{array}{c}\text { Pyrite-Au-Ag sulfides/sulfosalts, } \\
\text { variable sphalerite, galena, } \\
\text { chalcopyrite, } \\
\text { tetrahedrite/tennantite }\end{array}$ \\
\hline Metals & $\begin{array}{l}\mathrm{Au}-\mathrm{Ag}-\mathrm{As}-\mathrm{Sb}-\mathrm{Se}-\mathrm{Hg} \text {-Tl; low } \mathrm{Au}-\mathrm{Ag} \\
\text { ratio; }<0.1-1 \% \text { (base metal) }\end{array}$ & $\begin{array}{c}\text { Au-Ag-Pb-Zn-Ba-Mn-Se; high } \\
\text { Ag/ Au ratio; } 2-10 \% \text { (base metal) }\end{array}$ \\
\hline $\begin{array}{l}\text { Hydrothermal } \\
\text { Fluids }\end{array}$ & $\begin{array}{c}<1 \text { wt. } \% \mathrm{NaCl} \text { eq., rich of gas, } \\
<220^{\circ} \mathrm{C}\end{array}$ & $3-10$ wt. $\% \mathrm{NaCl}$ eq., $220-280^{\circ} \mathrm{C}$ \\
\hline
\end{tabular}

by the presence of disseminated ore minerals in the altered host rock.

\section{CONCLUSION}

The alteration and the ore mineralization are estimated to be occurred in Upper Oligocene - Lower Miocene, after the uplifting of $\mathrm{Ku}$ lon Progo (with NNE-SSW compressional stress), that causes the uplifting and erosion of Nanggulan Formation, which leaves a little part of that formation (quartz wacke rock unit) and cause the intrusive andesit 1 unit unveiling. That compression also responsible for the generation of NE-SW sinistral strike slip fault, predictable normal fault (dilational jog) (NNW-SSE). It also assumed to generate NNE-SSW normal faults, as channelways for magma to flow and form the intrusive andesite 2 unit, intrusive andesite 3 unit, and intrusive dacitic andesite rock unit. The tension fractures (NW-SE and NE-SW) occur as a result of the previous compressional stress release. The dilational jog and the tension fractures have an important role as channelways of hydrothermal fluid to flow to the shallower depth and yield the alteration and ore mineralization zones. Those latter structures, also responsible for the formation of diatreme breccia and andesite dike. At the extensional phase, the formation of WNW-ESE oblique normal faults and the NWSE predictable normal fault occurred. Those faults also have big contribution for the existence of alteration and ore mineralization in the research area, although in the lower intensity.

The epithermal deposit in the research area is classified as deep low sulfidation epithermal deposit. The geochemistry of the hydrothermal alteration can be identified from the $\mathrm{K}_{2} \mathrm{O}$ enrichment throughout the alteration zones, not only as the identification-mark in the silicaclay alteration zone, but also as overprinting mineral in the other alteration zones. The ore mineral is precipitated by three processes, including boiling, mixing, and wall rock sulfidation, with the grade of $\mathrm{Cu}, \mathrm{Zn}, \mathrm{Pb}, \mathrm{Ag}$, and As up to 5,171 ppm, 8,995 ppm, 6,398 ppm, $34.1 \mathrm{ppm}$, and 1,010.5 ppm. The hydrothermal fluid in the research area is classified as an aqueous, liquid-rich, and two-phase inclusion, with homogenization temperature ranges from 
242.1-257.6 ${ }^{\circ} \mathrm{C}$, and salinity of $1.57-3.87$ wt.\% $\mathrm{NaCl}$ equiv. Those values indicate the depth of the deposit ranged from 384-516 m below the paleosurface, and pressure of 102-137 bar. There are three processes which control the hydrothermal fluid evolution in the research area, involving boiling, heating, and isothermal mixing.

\section{ACKNOWLEDGEMENTS}

Authors would like to thank to Department of Geological Engineering, Universitas Gadjah Mada for partly financial support, granted to the second author. Laboratory analyses were mostly conducted by first author in Economic Geology laboratories, Department of Earth Resources Engineering, Kyushu University. Those were only possible to be done through JASSO scholarship awarded to first author. Continuous supports from Dr. Kotaro Yonezu and Prof. Koichiro Watanabe, Ph.D. are highly appreciated and thankful.

\section{REFERENCES}

Carlile, J.C., Mitchell, A.H.G. (1994) Magmatic Arcs and Associated Gold and Copper Mineralization in Indonesia, Journal of Geochemical Exploration 50: 91-142.

Cooke, D.R., Simmons, S.F. (2000) Characteristics and Genesis of Epithermal Gold Deposits, In: SEG Reviews 13: 221-224.

Harjanto, A. (2011) Volkanostratigrafi di Daerah Kulon Progo dan Sekitarnya, Daerah Istimewa Yogyakarta, Jurnal Ilmiah MTG 4: 30-46.

Hedenquist, J.W., Arribas, A., Jr., Gonzalez-Urien, E. (2000) Exploration for Epithermal Gold Deposits, In: SEG Reviews, Economic Geology 13: 245-277.

Idrus, A., Kolb, J., Meyer, F.M. (2009) Mineralogy, Lithogeochemistry, and Elemental Mass Balance of Hydrothermal Alteration Associated with The
Gold-rich Batu Hijau Porphyry Copper Deposit, Sumbawa Island, Indonesia, Resource Geology 59: 215-230.

Morrison, G., Dong, G., Jaireth, S. (1990) Textural Zoning in Epithermal Quartz Veins, Klondike Exploration Services, Townsville, 35p.

Petrelli, M., Poli, G., Perugini, D., Peccerillo, A. (2005) Petrograph: A New Software to Visualize, Model, and Present Geochemical Data in Igneous Petrology, Geochemistry, Geophysics, Geosystems, vol. 6(7), 15p.

Rahardjo, W., Sukandarrumidi, Rosidi, H.M.D. (1995) Peta Geologi Lembar Yogyakarta, Jawa, Edisi 2, Pusat Penelitian dan Pengembangan, Bandung.

Shepherd, T.J., Rankin, A.H., Alderton, D.H.M. (1985) A Practical Guide to Fluid Inclusion Studies, Blackie \& Son Limited, Glasgow, 239p.

Sillitoe, R.H., Hedenquist, J.W. (2003) Linkages Between Volcanotectonic Settings, Ore-Fluid Compositions, and Epithermal Precious Metal Deposits, Society of Economic Geologists, Special Publication 10, pp. $315-343$.

Simmons, S.F., White, N.C., John, D.A. (2005) Geological Chacteristics of Epithermal Precious and Base Metal Deposits, Society of Economic Geologists, Economic Geology, 100th Anniversary Volume, pp. 485-522.

Soeria-Atmadja, R., Maury, R.C., Bellon, H., Pringgoprawiro, H., Polves, M., Priadi, B. (1994) Tertiary Magmatic Belts in Java, Journal of Southeast Asian Earth Science 9: 13-27.

Suroso, Rodhi, A., Sutanto (1986) Usulan Penyesuaian Tata Nama Litostratigrafi Kulon Progo, Daerah Istimewa Yogyakarta, Proceeding of The $15^{\text {th }}$ Annual Convention of The Indonesian Association of Geologists, vol. 1, 10p.

Van Bemmelen, R.W. (1949) The Geology of Indonesia, vol. IA, General Geology of Indonesia and Adjacent Archipelagoes, $2^{\text {nd }}$ Second Edition, The Hague, Netherlands, 732p.

Wilkinson, J.J. (2001) Fluid Inclusion in Hydrothermal Ore Deposits, Lithos 55: 229 - 272. 